Gulawentah: Jurnal Studi Sosial

ISSN 2528-6293 (Print); ISSN 2528-6871 (Online)

Vol. 4, No. 2, Desember 2019, Hal 85-92

Tersedia Online: http://e-journal.unipma.ac.id/index.php/gulawentah

\title{
Pemanfaatan Media Digital Terhadap Indeks Minat Baca Masyarakat Kabupaten Lamongan
}

\author{
Abd. Ghofur dan Evi Aulia Rachma \\ STKIP PGRI Lamongan, Jl. Sunan Kalijogo Kabupaten Lamongan 62214, Indonesia \\ Email: ghofurkita@yahoo.com; eviauliarachma134@gmail.com
}

\begin{abstract}
Abstrak
Membaca merupakan aktivitas yang sangat penting dalam masyarakat. Selain untuk menambah informasi, juga untuk menambah ilmu pengetahuan dan wawasan berpikir yang luas. Munculnya Internet dan situs media sosial telah memperluas sumber informasi berbasis digital. Perilaku membaca masyarakatpun berubah, hal ini tentu meningkatkan minat baca masyarakat. Melalui permasalahan tersebut penelitian ini bertujuan untuk menganalisis pengaruh pemanfaatan media digital terhadap indeks minat baca masyarakat Lamongan. Penelitian ini menggunakan metode penelitian survei deskriptif dengan pendekatan kuantitatif. Sampel penelitian diambil 578 responden mulai usia 16 tahun keatas yang berasal dari 7 kecamatan dengan menggunakan multi stage technique sampling. Instrumen pengumpulan data dengan kuesioner, wawancara, observasi dan dokumentasi. Analisis data yang digunakan dalam penelitian ini adalah analisa deskriptif kuatitatif. Berdasarkan hasil penelitian dapat disimpulkan bahwa minat baca masyarakat Kabupaten Lamongan tahun 2019 adalah sebesar 64,71\%. banyak masyarakat yang membaca namun ternyata mereka lebih suka membaca melalui internet dengan media Handphone atau Smartphone dari pada laptop dan komputer.
\end{abstract}

Kata kunci: Media Digital; Indeks Minat Baca

\section{Using Digital Media for the Reading Interest Index of the Lamongan District Community}

\begin{abstract}
Reading is a very important activity in society. In addition to adding information, also to increase knowledge and broad thinking insight. The rise of the Internet and social media sites has expanded digital-based information sources. The reading behavior of the people has changed, this certainly increases the interest in reading the community. Through these problems, this study aims to analyze the effect of the use of digital media on the reading index of the Lamongan community. This study uses a descriptive survey research method with a quantitative approach. The study sample was taken 578 respondents starting at age 16 and above originating from 7 districts using multi stage technique sampling. Data collection instruments with questionnaires, interviews, observation and documentation. Analysis of the data used in this research is descriptive quantitative analysis. Based on the results of the study it can be concluded that the reading interest of the people of Lamongan District in 2019 is 64.71\%. Many people who read but it turns out they prefer to read via the internet with mobile media or smartphones than on laptops and computers.
\end{abstract}

Keywords: Digital Media; Reading Interest Index

DOI: $10.25273 /$ gulawentah.v4i2.5524

Copyright (C) 2019 Universitas PGRI Madiun

All rights reserved. 


\section{Pendahuluan}

Membaca merupakan aktivitas yang sangat penting dalam masyarakat dan merupakan langkah awal membina minat baca. Membaca bisa menambah informasi, pengetahuan, dan wawasan berpikir yang luas. Menurut Shari (2006), membaca dianggap sebagai proses, cara berpikir, semacam pengalaman kehidupan nyata serta melibatkan banyak keterampilan yang kompleks. Minat baca menurut Meliyawati (2016), merupakan perasaan yang timbul dalam hati yang diiringi dengan adanya dorongan yang kuat untuk membaca. Sedangkan menurut Squires (2014), minat baca merupakan suatu gambaran seseorang tentang seberapa bersemangat dan antusias ketika mereka melakukan kegiatan membaca. Sehingga dapat disimpulkan bahwa minat baca dapat diartikan sebagai suatu kecenderungan seseorang yang ditandai dengan munculnya perasaan ketertarikan akan bahan bacaan dan aktivitas membaca, sehingga akan menyebabkan seseorang melakukan kegiatan membaca secara sukarela, dimana dalam kegiatan membaca tersebut melibatkan sikap yang menikmati dan ingin terus membaca dalam jangka waktu yang panjang dan berkelanjutan.

Menurut hasil penelitian Perpustakaan Nasional pada tahun 2017 bahwa rata-rata orang Indonesia hanya membaca buku 3-4 kali per minggu, dengan durasi waktu membaca per hari ratarata 30-59 menit. Sedangkan, jumlah buku yang ditamatkan per tahun rata-rata hanya 5-9 buku. Data yang dirilis Perpusnas juga menunjukan bahwa tingkat kegemaran membaca masyarakat Indonesia hanya 36,48 atau tergolong rendah. Rendahnya minat baca masyarakat Indonesia juga dikuatkan oleh sebuah studi yang dilakukan Central Connecticut State University pada tahun 2016 mengenai "Most Literate Nations in The World". Studi tersebut menyebutkan bahwa Indonesia menempati urutan ke-60 dari total 61 negara, atau dengan kata lain minat baca masyarakat Indonesia disebut-sebut hanya sebesar 0,01 persen atau satu berbanding sepuluh ribu. Ironinya, angka ini berbanding terbalik dengan jumlah pengguna internet yang mencapai separuh dari total populasi penduduk Indonesia atau sekitar Rp 132,7 juta.

Rendahnya minat baca di Indonesia, menurut Colin McElwee, Co-Founder Worldreader, salah satunya dipengaruhi oleh sulitnya akses terhadap buku. Tak hanya itu, Colin juga mengatakan bahwa gempuran inovasi di bidang teknologi membuat masyarakat terutama generasi milenial lebih senang menatap layar gawai dibandingkan membaca buku. Munculnya Internet dan situs media sosial telah memperluas sumber informasi berbasis digital (Schneider, 2010). Martinez dan LópezRío (2015) juga mengungkapkan bahwa kemunculan teknologi dan intenet telah menyebabkan adanya cara membaca yang baru. Selain itu, menurut Aydemir dan Ozturk (2012) membaca digital merupakan suatu dampak yang diakibatkan oleh munculnya budaya digital, sehingga seringkali disebut sebagai reading from the screen.

Pesan di media online, terutama media sosial mempunyai karakteristik tersendiri. Karakteristik tersebut antara lain, semua orang dapat menciptakan informasi, penyebaran informasi sangat cepat dan dapat dilakukan serentak, pesan dapat disampaikan dengan singkat, serta adanya interaksi diantara para pengguna media sosial, baik itu dilakukan secara non real-time ataupun realtime. Kemudahan akses media digital tersebut membuat perilaku membaca masyarakatpun berubah. Dunia akan terasa ada dalam genggaman ketika seseorang memegang gadget. Setiap saat kita bisa membaca dimanapun dan kapapun, baik itu membaca konten web, konten berita, e-book, e-mail, e-journal dan sebagainya. Akses terhadap bahan bacaan begitu mudah. Di satu sisi, hal ini membuat orang ingin serba cepat dalam membaca pesan. Sehingga terkadang seseorang membagi informasi dalam bahan bacaan tanpa mengecek akurasinya. Semua orang seakan berlomba untuk menjadi orang pertama yang tahu dan membagikan informasi kepada orang lain.

Di sisi lain ini merupakan potensi bagi kebangkitan minat baca seseorang. Banyak orang mengaktualisasikan dirinya melalui media sosial, dimana kita bisa memanfaatkan hal tersebut untuk mempopulerkan budaya baca bagi masyarakat. Dengan perubahan perilaku membaca tersebut, minat baca tidak lagi hanya dilihat dari berapa banyak buku dibaca, tetapi juga berapa banyak sumber-sumber informasi atau bahan bacaan online di-klik, dibaca, dibagikan, didiskusikan, disimpan atau di-download. Oleh karena itu, tujuan umum dari penelitian ini adalah 
untuk menganalisis pengaruh pemanfaatan media digital terhadap indeks minat baca masyarakat lamongan.

\section{Metode Penelitian}

Pada Penelitian ini digunakan metode penelitian survei deskriptif dengan menggunakan pendekatan kuantitatif. Penelitian ini dilaksanakan selama kurun waktu 4 bulan, terhitung sejak bulan April hingga bulan Juli 2019. Sampel penelitian diambil 578 responden mulai usia 16 tahun keatas yang tersebar di 7 (tujuh) kecamatan yang ada di Kabupaten Lamongan yang mewakili dari masing-masing Daerah Pemilihan (Dapil) I sampai dengan V, yaitu Kecamatan Lamongan, Sugio, Modo, Babat, Brondong, Paciran dan Karanggeneng. Pengambilan subyek penelitian dengan menggunakan multi stage technique sampling. Instrumen pengumpulan data dengan kuesioner, wawancara, observasi dan dokumentasi. Analisis data yang digunakan dalam penelitian ini adalah analisa deskriptif kuantitatif. Penyajian data dibuat dalam bentuk deskriptif yang bertujuan memberikan deskripsi mengenai subyek penelitian berdasarkan data dari variabel yang diperoleh dari kelompok subyek yang diteliti dengan menggunakan tehnik tabulasi, dengan menyajikan hasil penelitian tabel/bagan/grafik distribusi frekuensi dengan persentase untuk masing-masing kelompok.

\section{Hasil dan Pembahasan}

\section{Klasifikasi Responden}

Berdasarkan gambar 1 di bawah ini menunjukkan klasifikasi responden berdasarkan dua kategori, yakni kategori Mahasiswa/pelajar, dan kategori masyarakat umum. Jika dilihat dari komposisinya pelajar/mahasiswa memiliki persentase sebanyak $40,24 \%$ sedangkan masyarakat umum sekitar 59,76\%.

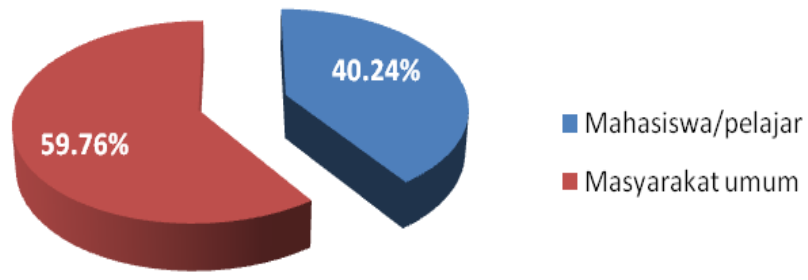

Gambar 1. Klasifikasi responden berdasarkan kategori umum

Jika diklasifikasi lebih detail lagi, maka diketahui bahwa masyarakat umum yang terlibat dalam penelitian ini diantaranya yang terdiri dari guru/dosen, wiraswasta, Polisi/TNI, PNS, pegawai swasta, petani/nelayan, buruh, ibu rumah tangga, perangkat desa, dan lainnya.

\section{Usia Responden}

Distribusi responden jika didasarkan pada aspek usia dalam kajian ini adalah berkisar antara usia 16 tahun sampai dengan usia diatas 25 tahun. Sedangkan usia responden di klasifikasikan kedalam 3 kategori yaitu usia 16-19 tahun dalam kategori remaja awal, usia 20-25 termasuk kategori remaja akhir, dan usia diatas 25 tahun termasuk kategori dewasa. Sebagaimana halnya yang dapat kita lihat pada gambar 3.2 bahwa responden yang berusia 16 sampai 19 tahun yang tergolong remaja awal ada sekitar $29,1 \%$ dan posisi kedua adalah remaja akhir yang berusia antara 20-25 tahun sebanyak $37.8 \%$, sedangkan yang termasuk dewasa atau usia diatas 25 tahun ada sekitar $32.87 \%$. Ini berarti komposisi usia diantara ketiga kelompok tidak terlalu beda secara signifikan. Secara visual distribusi responden yang dikaji berdasarkan usianya bisa dilihat gambar 2 di bawah ini. 


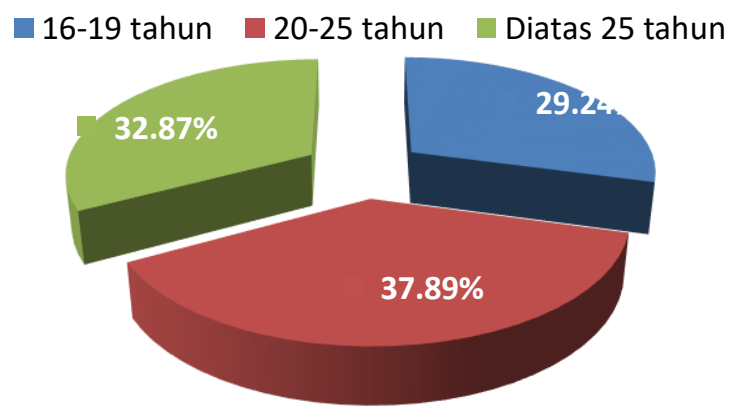

Gambar 2. Klasifikasi responden berdasarkan usia

\section{Pendidikan Responden}

Distribusi pendidikan responden dalam kajian ini kebanyakan adalah lulus SMA atau sederajat yaitu sebesar $52,77 \%$, sedangkan terbanyak kedua adalah pendidikan sarjana (S1) yakni sebanyak $31.14 \%$, sedangkan terbanyak ketiga adalah berpendidikan SMP atau sederajat yaitu sebanyak $9.34 \%$. Kemudian sisanya sebanyak 3.29\% berpendidikan magister (S2), dilanjutkan berpendidikan Diploma sebanyak $2.94 \%$, dan $0.52 \%$ responden berpendidikan doktor (S3).

Distribusi responden berdasarkan latar belakang pendidikan dalam kajian ini adalah seperti yang dapat kita lihat pada gambar 3.

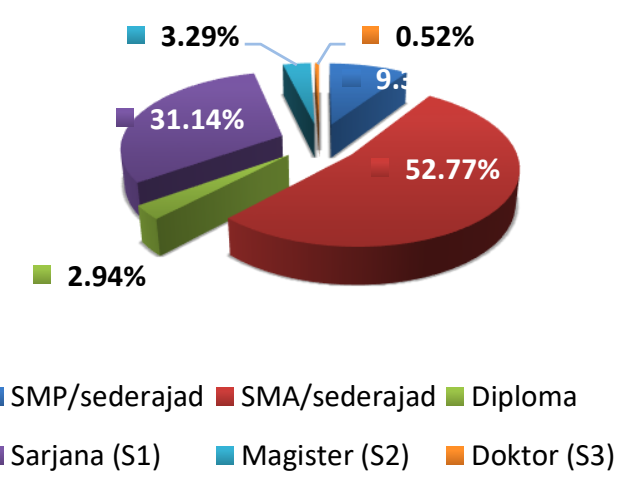

Gambar 3. Klasifikasi responden berdasarkan usia

Minat Baca Responden

Hasil survei tentang minat baca masyarakat Lamongan dapat kita lihat pada gambar 3.4 yang menunjukkan Minat membaca Responden dalam kajian ini, yaitu menunjukkan bahwa dari 578 responden yang memiliki minat baca adalah sekitar 374 atau $64,71 \%$, sedangkan yang tidak memiliki minat baca sekitar 204 atau 35,29\%.

घuruf latin dan arab $\square$ Huruf latin saja $\square$ Tidak bisa baca

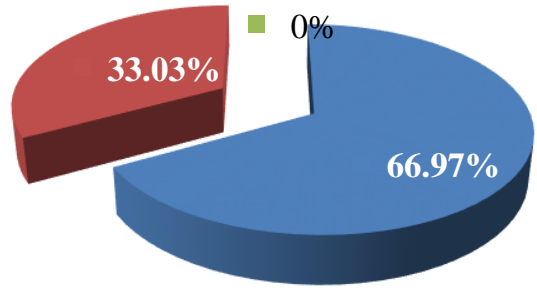

Gambar 4. Minat baca responden 
Hal ini menunjukkan bahwa minat baca masyarakat di Lamongan tergolong cukup tinggi, yaitu mencapai $64.71 \%$. Namun demikian masih perlu di tingkatkan lagi menjadi lebih baik lagi, agar minat baca menjadi budaya masyarakat. Sehingga masyarakat menjadi terbiasa untuk gemar membaca. Hal ini juga sudah menjadi bagian dari upaya Dinas Perpustakaan melalui perpustakaan keliling, pengadaan perpustakaan desa melalui program dana desa, lembaga pendidikan dan instansi lainnya yang terus berupaya mendorong adanya program pojok baca

\section{Distribusi Kegemaran Responden terhadap Jenis Bacaan}

Diketahui bahwa tema yang paling banyak dibaca adalah jenis bacaan sosial, yakni buku yang berkaitan dengan aktivitas sosial kemasyarakatan, atau buku bacaan ilmu pengetahuan sosial.Responden yang gemar membaca buku ini sebanyak 22.34\%. Dilanjutkan buku yang bertemakan agama sebanyak $17.53 \%$, lalu buku yang bertemakan sejarah sebanyak $15.46 \%$, kemudian dilanjutkan buku yang bertemakan sastra, seperti seperti komik, cerpen, novel dan cerita lainnya. Selain jenis bacaan tersebut dari mereka ada juga yang memiliki kegemaran membaca di bidang, bahasa, teknologi, seni, dan lainnya, seperti buku motivasi.Secara visual, beragam tema bacaan yang digemari oleh responden bisa dilihat pada gambar 5 .

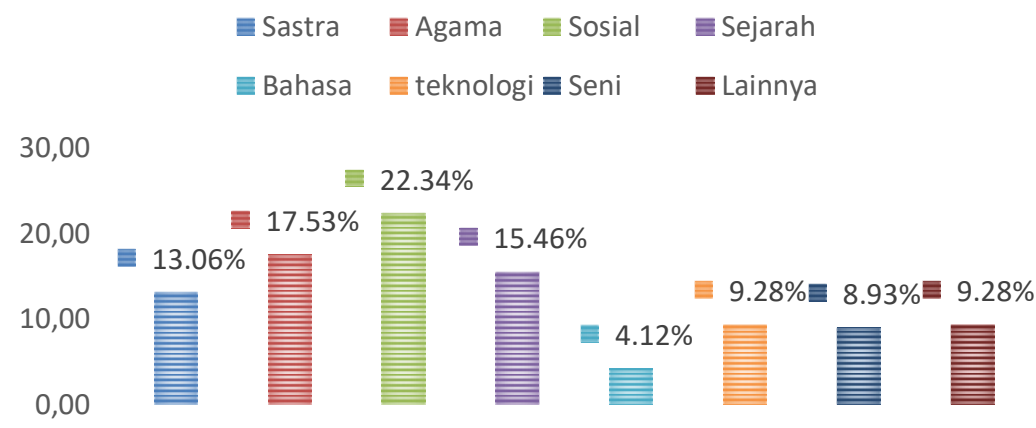

Gambar 5. Jenis tema bacaan yang digemari

\section{Distribusi Kegemaran Responden terhadap Jenis Bacaan di Internet}

Secara visual konten internet yang sering diakses oleh para responden bisa diketahui pada gambar 6 di bawah ini.

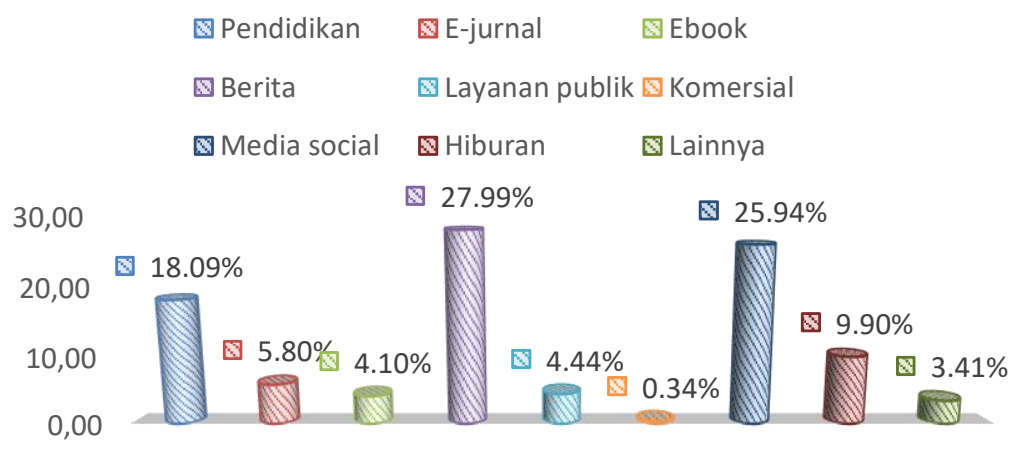

Gambar 6. konten internet yang sering diakses

Distribusi responden tentang bidang apa yang sering dibaca di Internet dapat dilihat pada gambar 3.6 dimana sekitar 27.99\% responden mengakui bahwa mereka sering menggunakan akses internet untuk membaca berita online. Berita ini merupakan kabar kejadian yang secara umum 
terjadi dalam kehidupan manusia. Mereka mengatakan bahwa berita di media online lebih up to date dan sangat mudah diakses daripada berita dalam bentuk cetak.

Kemudian peringkat kedua untuk layanan internet yang sering diakses oleh para responden adalah media sosial, yakni sebanyak $25.94 \%$. Media sosial merupakan sebuah media daring, dengan para penggunanya bisa dengan mudah berpartisipasi, berbagi, dan menciptakan isi meliputi jejaring sosial, seperti Facebook, instragram dan lainnya. Berikutnya yang paling banyak diakses adalah bidang pendidikan, yakni sebanyak 18.09\%, dilanjutkan dengan hiburan seperti game, film dan hiburan lainnya sebanyak $9.90 \%$. Selanjutnya adalah responden paling sering mengakses $e$ journal $(5.80 \%)$, dan e-book sebanyak (4.10\%). Mereka yang mengakses ini kebanyakan guru, dosen, dan mahasiswa yang karena tugas dan kewajiban mereka dalam menunjang profesi masingmasing. Berikutnya yang sering diakses oleh para responden adalah layanan komersial seperti iklan, toko online dan beberapa aplikasi komersial lainnya sebanyak $0.34 \%$ dan sisanya sebanyak $3.41 \%$ memilih beragam aplikasi internet lainnya.

\section{Perangkat yang digunkan Responden dalam mengakses Internet.}

Secara visual perangkat yang sering digunakan untuk mengakses internet oleh para responden bisa diketahui pada gambar 7 di bawah ini.

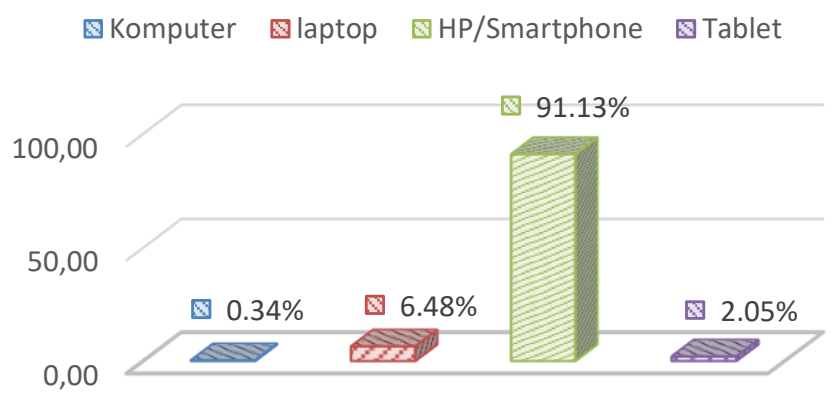

Gambar 7. Perangkat yang anda gunakan untuk mengakses Internet

Berdasarkan analisis data diketahui bahwa kebanyakan responden akses internet melalui handphone atau smartphone yang mereka miliki, yaitu sebanyak 91,13\%, sedangkan sisanya respoden mengatakan sering mengakses internet dengan menggunakan laptop sebanyak 6,48\%, lalu menggunakan perangkat dalam bentuk tablet sebanyak $2.05 \%$, dan sisanya para responden mengakses internet dengan menggunakan komputer, yakni sebanyak $0.34 \%$.

Berdasarkan data tersebut diketahui bahwa penggunaan komputer untuk aktivitas akses internet sudah jarang sekali dilakukan oleh masyarakat. Hal ini disebabkan oleh semakin banyaknya HP/smartphone yang aplikasinya didesain sangat lengkap untuk layanan akses internet. Selain itu, dengan sangat mudahnya akses internet dengan HP/smartphone yang mereka miliki diketahui bahwa mereka lebih suka membaca melalui internet dengan media Handphone atau Smartphone dari pada laptop dan komputer, hal ini disebabkan perangkat tersebut mudah dimiliki dan dibawa kemanapun berada dan dengan mudah dapat digunakan untuk mengakses internet.

\section{Pengaruh Pemanfaatan Media Digital terhadap Indeks Minat Membaca Masyarakat}

Berdasarkan hasil analisis bagan maupun grafik distribusi frekuensi dengan persentase untuk masing-masing kelompok diatas dapat dijelaskan bahwa kemunculan media digital meningkatkan minat baca masyarakat Lamongan. Saat ini, akses mudah terhadap media digital merupakan tantangan besar bagi kebiasaan membaca masyarakat. Tentunya, banyak orang membutuhkan teknologi dalam bentuk internet untuk memproses informasi secara bersamaan, berbagi, maupun berdiskusi (Tanjung, Ridwan, \& Gultom, 2017). Kenyamanan mereka dalam menggunakan teknologi, misal ponsel pintar atau tab membuatnya lebih suka perangkat ini daripada dokumen cetak. 
Saaid dan Wahab (2014) mengatakan bahwa banyaknya informasi digital yang tersedia dapat meningkatkan waktu yang dihabiskan sesorang untuk membaca melalui media elektronik. Lingkungan digital sudah mempengaruhi kebiasaan orang-orang dalam membaca. Kebiasaan membaca mereka telah berubah dan minat mereka dalam membaca telah berkembang karena munculnya publikasi digital seperti surat kabar, majalah, buku, dan jurnal secara online. Hal ini juga sesuai dengan penelitian yang dilakukan oleh Long dan Szabo (2016) bahwa seseorang yang menggunakan aplikasi bacaan digital sebagai media membaca mengalami peningkatan yang positif terkait motivasinya dalam membaca.

Era digital juga melahirkan generasi digital native. Generasi digital native adalah mereka yang lahir pada jaman teknologi sehingga sejak usia dini mereka sudah berinteraksi dengan media digital. Mereka hidup di era internet, gadget, dan IoT (Internet of Things). Lebih lanjut, internet memungkinkan orang untuk mempelajari sesuatu melalui proses yang cepat dan mengharapkan konten dalam format yang ringkas dan mudah dicerna (Verma \& Malviya, 2014). Menurut Tapscott (2008), generasi tersebut memilih kebebasan untuk membuat pilihan dalam hidup dan mereka ingin memasukkan banyak hal ke tangan mereka sendiri. Inovasi juga merupakan bagian dari kehidupan mereka. Kemudahan akses media digital tersebut mempengaruhi perubahan perilaku membaca pada masyarakat. Minat baca tidak lagi hanya dilihat dari berapa banyak buku dibaca, tetapi juga berapa banyak sumber-sumber informasi atau bahan bacaan online di-klik, dibaca, dibagikan, didiskusikan, disimpan atau di-download.

\section{Simpulan}

Berdasarkan hasil survei menyimpulkan bahwa minat baca masyarakat Kabupaten Lamongan tahun 2019 adalah sebesar 64,71\%. Usia masyarakat yang gemar membaca untuk remaja awal (16-19 tahun) sebanyak 19.38\%, untuk remaja akhir (20-25 tahun) sebanyak 26.47\%, sedangkan untuk kategori dewasa (Diatas 25 tahun) sebanyak 18.86\%. Pendidikan Responden yang gemar membaca adalah mereka yang berpendidikan SMA dan sederajat yaitu 34.26\%, dan yang terbanyak kedua adalah lulusan Perguruan tinggi. Pekerjaan masyarakat yang memiliki minat baca adalah berasal dari kalangan pelajar/mahasiswa. Selain pelajar/mahasiswa adalah guru/dosen, dan wiraswasta. Masyarakat gemar membaca di perpustakaan tentang sosial, yakni sebanyak $22.34 \%$, selain jenis bacaan sosial dari mereka ada juga yang memiliki kegemaran membaca di bidang agama, sastra, sejarah, bahasa dan teknologi, serta lainnya. Masyarakat juga gemar membaca melalui internet tentang berita, media sosial (facebook, instagram, dll) hiburan seperti lagu-lagu, film dan hiburan lainnya, Pendidikan seperti E-journal, E-book dan e-artikel dan yang lain adalah layanan publik seperti iklan, toko online dan lainnya. Perangkat yang digunakan Responden dalam mengakses Internet kebanyakan melalui handphone atau smartphone, yakni sebanyak $91.13 \%$. Selain itu ada juga yang menggunakan laptop dan komputer walaupun tidak banyak. Dengan demikian dapat disimpulkan bahwa banyak masyarakat yang membaca namun ternyata mereka lebih suka membaca melalui internet dengan media Handphone atau Smartphone dari pada laptop dan komputer.

Daftar Pustaka

Aydemir, Z., \& Ozturk, E. (2012). The Effects of Reading from the Screen on the Reading Motivation Levels of Elementary 5th Graders. Turkish Online Journal of Educational Technology-TOJET, 11(3), 357-365.

Long, D., \& Szabo, S. (2016). E-readers and the effects on students' reading motivation, attitude and comprehension during guided reading. Cogent education, 3(1), 1197818.

Martinez, V. G., \& López-Río, J. (2015). About the horrific peril of reading on digital devices. Procedia-Social and Behavioral Sciences, 178, 105-109.

Gulawentah: Jurnal Studi Sosial

Vol. 4, No. 2, Desember 2019, hal 85-92 
Meliyawati, M. (2016). Pemahaman Dasar Membaca. Yogyakarta: Depublis.

Saaid, S. A., \& Wahab, Z. A. (2014). The Impact of Digital-Based Materials on Undergraduates' Reading Habit. International Journal of Social Science and Humanity, 4(3), 249.

Schneider, N. (2010). Facebook, Other Social Network Sites Could Lead to Lower Grades for Students. In.

Shari, M. (2006). Male teenagers need for extensive reading. In.

Squires, S. (2014). The effects of reading interest, reading purpose, and reading maturity on reading comprehension of high school students: Baker University.

Tanjung, F. Z., Ridwan, R., \& Gultom, U. A. (2017). Reading Habits in Digital Era: A Research on the Students in Borneo University. LLT Journal: A Journal On Language And Language Teaching, 20(2), 147-157.

Tapscott, D. (2008). Grown up digital: McGraw-Hill Education Boston.

Verma, J., \& Malviya, V. (2014). The impact of internet and digital media on reading habit. Paper presented at the XXIV National Seminar of the IASLIC. 